\title{
DIMENSÃO ESPIRITUAL E PSICOLOGIA: A BUSCA PELA INTEIREZA
}

\author{
Spiritual dimension and psychology: the quest for wholeness. \\ Dimensión espiritual y psicología: la búsqueda por la entereza.
}

ANANDA K. C. NASCIMENTO Marcus T. CALDAS

\begin{abstract}
Resumo: Este artigo teve como objetivo pesquisar a dimensão espiritual na psicologia a partir das linhas de pensamento de Viktor Emil Frankl, fundador da Logoterapia e da Análise Existencial, e de Carl Gustav Jung, criador da Psicologia Analítica. Para tanto, utilizamos o método bibliográfico, primando pelo uso das obras dos autores e de intérpretes destes autores mais contemporâneos. A logoterapia se destacou por mostrar ser um método terapêutico estruturado com metas, procedimentos e técnicas facilitadoras específicas ao paciente que experiencia algum tipo de sofrimento existencial a buscar e encontrar sentido. A psicologia analítica demonstrou que a psicoterapia vislumbra favorecer o processo de desenvolvimento psíquico do indivíduo, isto é, a tomada de consciência, através da aproximação do eixo ego-Self. Assim, valoriza a influência do arquétipo Imago Dei nos níveis coletivo e individual, e a experiência consciente da religiosidade. Portanto, concluímos que, as ideias de Frankl e Jung demonstram mais aproximações que afastamentos no que se refere às influências filosóficas, à compreensão da importância das experiências conscientes do ser humano com a religiosidade e a espiritualidade em busca da integração, unidade e inteireza das dimensões que o constitui. Diferindo na compreensão do fundamento da dimensão espiritual no homem.
\end{abstract}

Palavras-chave: Religião; Espiritualidade; Psicoterapia; Psicologia.

Abstract: This article aimed to research the spiritual dimension in psychology from the lines of thought of Viktor Emil Frankl, founder of Logotherapy and Existential Analysis, and Carl Gustav Jung, creator of Analytical Psychology. To do so, we use the bibliographic method, emphasizing the use of the works of the authors and more contemporary interpreters of these authors. Logotherapy excelled for showing to be a therapeutic method structured with goals, procedures and facilitating techniques specifics for the patient who experiences some kind of existential suffering to seek and find meaning. Analytical psychology has showed that the psychotherapy envisions favoring the individual's process of psychic development, that is, awareness of consciousness, through the approach of the ego-Self axis. In this context, it values the influence of the Imago Dei archetype at the collective and individual levels, and the conscious experience of religiosity. Therefore, we conclude that the ideas of Frankl and Jung show more approximations than distances in relation to philosophical influences, the understanding of the importance of the conscious experiences of the human being with religiosity and spirituality in search of integration, unity, and wholeness of his dimensions. Differing in the understanding of the foundation of the spiritual dimension in man.

Keywords: Religion; Spirituality; Psychotherapy; Psychology.

Resumen: Este artículo tuvo como objetivo investigar la dimensión espiritual en la psicología a partir de las líneas de pensamiento de Viktor Emil Frankl, fundador de la Logoterapia y del Análisis Existencial, y de Carl Gustav Jung, creador de la Psicología Analítica. Para ello, utilizamos el método bibliográfico, primando por el uso de las obras de los autores y de intérpretes de estos autores más contemporáneos. La logoterapia se señaló por mostrar ser un método terapéutico estructurado con metas, procedimientos y técnicas facilitadoras específicas al paciente que experimenta algún tipo de sufrimiento existencial a buscar y encontrar sentido. La psicología analítica demostró que la psicoterapia vislumbra favorecer el proceso de desarrollo psíquico del individuo, es decir, la toma de conciencia, a través de la aproximación del eje ego propio. De esa manera, valora la influencia del arquetipo Imago Dei en los niveles colectivo e individual, y la experiencia consciente de la religiosidad. Por lo tanto, concluimos que, las ideas de Frankl y Jung demuestran más acercamientos que alejamientos en lo que se refiere a las influencias filosóficas, a la comprensión de la importancia de las experiencias conscientes del ser humano con la religiosidad y la espiritualidad en búsqueda de la integración, unidad y entereza de las dimensiones que lo constituye. Difiriendo en la comprensión del fundamento de la dimensión espiritual en el hombre.

Palabras-claves: : Religión; Espiritualidad; Psicoterapia; Psicología. 


\section{Introdução}

$\mathrm{Na}$ atualidade, ao investigarmos na literatura especializada a produção científica da ciência psicológica no que concerne à inter-relação entre as temáticas "religiosidade e espiritualidade" e a prática psicoterápica, constatamos que algumas abordagens psicológicas fundamentadas em certos referenciais teóricos se destacam nessa discussão, dentre elas a Logoterapia, a Psicologia Analítica e a Psicanálise.

A exemplo disso, Cavalheiro e Falcke (2014) realizaram uma pesquisa com psicólogos formados em diferentes abordagens teóricas sobre a relação destas com o Bem-Estar Espiritual. Através dos resultados, as autoras ponderaram que as experiências pessoais dos psicólogos com as suas religiosidade e espiritualidade influenciam nas eleições das abordagens teóricas, sendo o oposto também verdadeiro. Assim sendo, os participantes que apresentaram maior índice de Bem-Estar Espiritual, em detrimento a outras abordagens, foram das perspectivas teóricas: Humanismo, Gestalt, Sistêmica, Junguiana e Fenomenológico-Existencial.

Nesta direção, refletimos que a Logoterapia pode ser incluída nesta listagem por ser considerada a terceira força da psicoterapia vienense - precedida pela Psicanálise freudiana e pela Psicologia Individual adleriana -, pois compreende que o homem não é impulsionado, mas é atraído pelo sentido, ou seja, é dotado de uma vontade de sentido. Portanto, o homem é um ser que busca sentido, já que essa vontade o orienta intencionalmente, sendo atraída por um sentido de valor para a sua realização (Frankl, 1988/2007; Herrera, 2006). Assim, “a orientação intencional do ser humano aponta para um contexto onde se dão as experiências humanas. Por isso, os objetos não podem ser separados das experiências" (Herrera, 2006, p. 178, tradução nossa).

$\mathrm{Na}$ perspectiva frankliana, o homem é dotado de um suprassentido, isto é, um sentido último que "necessariamente excede e ultrapassa a capacidade finita do ser humano" (Frankl, 1977/2008, p. 142), o qual mesmo não sendo compreendido racionalmente existe incondicionalmente na vida, constituindo-se uma motivação humana primária nessa busca de sentido. Do mesmo modo, o sentido e o suprassentido se estabelecem como metas da Análise Existencial e da Logoterapia, visto que são dirigidas à dimensão existencial-espiritual do ser humano, facilitando que este descubra o sentido de sua existência (Herrera, 2006). Leia-se que, o termo "existencial" pode ser usado de três maneiras: referindo-se (1) à existência em si mesma, isto é, ao modo especificamente humano de ser; (2) ao sentido da existência; (3) à busca por um sentido concreto na existência pessoal, ou seja, à vontade de sentido (Frankl, 1977/2008, p. 126).

Em suma, a visão de homem de Frankl (1988/2007) compreende um composto formado não apenas pelas dimensões física e psicológica - mente e corpo -, mas por uma complexidade da totalidade humana combinada pelas dimensões somática, psíquica e espiritual, sendo esta última o que diferencia o homem dos vegetais e animais, assim como já propunha Max Scheler (2003). Porquanto, "reunião, autoconsciência e capacidade objetiva de resistência pulsional originária foram uma única estrutura ilacerável que, como tal, só é própria ao homem” (p. 39 , grifos do autor).

Nesse contexto, Herrera (2006) afirma que o homem é consciente "do desejo humano de alcançar a autorrealização ou a autoatualização" (p. 173, tradução nossa), porque há uma capacidade humana de autotranscendência da existência pertencente ao homem religioso que se apoia na fé, na busca de sentido para alcançar a felicidade e encontrar a quem amar (Aquino, Dantas, Medeiros, Moraes, Melo, Nascimento, Andrade, Abrantes, \& Pires, 2013). Isso tudo, de acordo com Frankl (1977/2008), é encontrado na realização de valores de criação e de experiência, e no sofrimento, pois estes compõem a existência.

Partindo do expandido, dentre as abordagens teóricas que compuseram o grupo apresentado pelas pesquisadoras Cavalheiro e Falcke (2014), destacamos a "Junguiana", isto porque, a Psicologia Analítica - conhecida como Abordagem Junguiana - também concebe o homem com uma existência espiritual (anteriormente, na filosofia, chamada de pneuma ou substância espiritual), o que o diferencia dos animais (Jung, 1976/2012g).

Frente aos diferentes entendimentos sobre religião e ciência, Chopra e Mlodinow (2012, p. 13) dizem que “"Deus” se refere tanto à uma divindade reguladora, como também ao conceito mais abrangente de uma presença divina no Universo". Neste sentido, Jung (1981/2012c) compreende Deus como um arquétipo primordial e universal, pertencente a toda humanidade por fazer parte do inconsciente coletivo, isto é, por ser uma percepção subjetiva da imagem de Deus - presença invisível - no inconsciente (Aquino et al., 2013). Já a religião está relacionada a uma experiência, uma vivência com o numinoso e, portanto, "é uma função natural da psique, é instintiva” (Spaccaquerche, 2010, p. 61) e pode materializar-se em instituições religiosas. Assim sendo, a Psicologia Analítica reconhece na religião e nas experiências religiosas de vários povos no mundo, um significado basilar à compreensão da estrutura da psique, tendo função regulatória da energia psíquica e sendo tida como uma das possíveis formas de expressão arquetípica mais arcaica da alma humana (Aquino et al., 2013).

A religião também é compreendida como uma possibilidade de religar - proveniente da etimologia da palavra religião, re-ligare - o ego ao self, isto é, o homem religioso quando sensibilizado pelos seus conteúdos inconscientes, projeta-os no mundo e, quando toma consciência da existência dessa instância arquetípica maior que sua experiência cons- 
ciente - ego -, vivencia sua espiritualidade de forma a buscar auxílio em si mesmo para suportar o sofrimento, atribuindo-lhe sentido em busca da inteireza (Jung, 1976/2012g).

Nessa direção, Dalgalarrondo (2008), afirma que, na perspectiva junguiana, a religiosidade é considerada como aspecto espontâneo, natural, arcaico e essencial à psique, portanto constitutiva à natureza humana, sendo experienciada no inconsciente coletivo devido à armazenagem e ao acúmulo dos aprendizados de milhares de gerações, os quais estão disponíveis a cada indivíduo. Por isso, a psicoterapia, nesta perspectiva, busca favorecer o processo de encontro no caminho do desenvolvimento psíquico "que leva à experiência religiosa, à experiência do Si-mesmo, permitindo-nos realizar a totalidade" (Spaccaquerche, 2010, p. 59). O que se refere ao processo de individuação, porque este diz respeito ao homem se desenvolver e se tornar si mesmo, único, ou seja, tem como meta o self (Si-mesmo). Então, o homem tende a ir em busca da completude, da inteireza, da unidade (Jung, 1976/2012g).

Contudo, esse processo de desenvolvimento psíquico não está relacionado ao egoísmo, ao individualismo e à supervalorização de si mesmo como tem sido difundido na atualidade; tampouco defende o ideal social da preponderância do coletivo e a renúncia do Si-mesmo. A proposta junguiana defende que haja uma cooperação entre a multiplicidade e a singularidade, o coletivo e o individual, para que essa unidade seja alcançada (Jung, 1971/2012f). Neste contexto, Jung (1976/2012g) compreende que essa unidade ao atingir a completude não se modifica, tal como é considerado Deus nas religiões, por isso que um dos simbolismos do self é a imagem de Deus, nomeada como imago Dei no homem. Isto, porque a imagem de Deus se trata de uma representação coletiva, presente no inconsciente coletivo, que é expressa no mundo consciente, transmitida em forma de ensinamentos por gerações, assumindo distintos moldes que variam de acordo com a consciência individual através da qual se manifesta.

Além do exposto, o que justifica nossa eleição por pesquisar a dimensão espiritual na psicologia a partir das linhas de pensamento de Viktor Emil Frankl, fundador da Logoterapia e da Análise Existencial, e de Carl Gustav Jung, criador da Psicologia Analítica, foi porque a primeira é o campo de interesse teórico do pesquisador, orientador e coautor deste artigo; e a segunda é a perspectiva que fundamenta teoricamente a psicoterapeuta e autora deste artigo.

Portanto, ainda que reconheçamos a legitimidade e a importância da contribuição de vários outros autores e abordagens teóricas à ciência psicológica, optamos por promover esse encontro por meio do destaque dos pensamentos destes reconhecidos autores no campo da psicoterapia que estabelecem interface com as temáticas religião e espiritualidade na prática psicoterápica. Destarte, instigados por questionamen- tos e diálogos inquietantes, optamos por nos debruçar sob a dimensão espiritual do humano e suas formas de expressão; inter-relacionando com a atual demanda humana que experiencia um momento sócio-histórico marcado pelo capitalismo e a supervalorização do individualismo e da competitividade.

\section{Método}

Foi utilizado o método de pesquisa bibliográfico como caminho para alcançar o objetivo deste artigo, visto que este faz uso de livros, artigos, dissertações e teses publicadas e disponíveis para que o pesquisador possa elaborar e desenvolver um profundo estudo a partir de leitura, reflexões, questionamentos e conversação crítica que permitam a criação de uma síntese integradora com considerações originais acerca da temática em questão (Gil, 1987/2002; Lima \& Mioto, 2007). Para tanto, utilizamos as principais obras dos autores em tese que abordam sobre nosso objeto de estudo - religião, espiritualidade e psicologia -, no intuito de sermos os mais fiéis possíveis aos seus pensamentos. Além disso, complementamos com intérpretes contemporâneos destes autores que versam sobre as temáticas em questão.

Insta destacar que as principais obras de Frankl utilizadas para compor este artigo foram: A presença ignorada de Deus, Em busca de sentido: um psicólogo no campo de concentração, Fundamentos y aplicaciones de la logoterapia, Psicoterapia e sentido da vida: fundamentos da logoterapia e análise existencial e Sede de sentido.

Já os volumes eleitos da obra completa de Jung foram: Aion: estudo sobre o simbolismo do si-mesmo, A energia psíquica, A natureza da psique, A prática da psicoterapia: contribuições ao problema da psicoterapia e à psicologia da transferência, A vida simbólica: escritos diversos, Escritos diversos: psicologia e religião ocidental e oriental (dos volumes 10 e 11), Mysterium coniunctionis: pesquisas sobre a separação e a composição dos opostos psíquicos na alquimia: Rex e Regina; Adão e Eva; A conjunção, $\mathrm{O}$ eu e o inconsciente, Os arquétipos e o inconsciente coletivo, Psicologia e religião: psicologia e religião ocidental e oriental, Sincronicidade: a dinâmica do inconsciente e Tipos psicológicos.

\section{Religiosidade, Espiritualidade e Psicoterapia na Psicologia.}

\subsection{Dimensão Espiritual na Logoterapia de Viktor Emil Frankl. \\ Viktor Emil Frankl (1905-1997, 92 anos) nasceu em Viena. Médico e Doutor em Filosofia. Foi pri- sioneiro nos campos de concentração durante a II Guerra Mundial. Fundou a Logoterapia e a Análise Existencial. Contribuiu significativamente para com}


as teorias e técnicas psicoterápicas a partir de sua visão acerca da estrutura ontológica complexa da integração do ser humano composta pelas dimensões física, psíquica e espiritual que atravessam os níveis consciente, pré-consciente e inconsciente.

Desse modo, a organização das dimensões do humano, de acordo com Frankl, (1988/2007), dá-se de modo estratificado concêntrico, ou seja, são divididas em camadas, nas quais os segmentos apresentam-se e se sobrepõem um ao outro, unidos por um único centro, e não são dispostas em subseções ou etapas, tal como podemos observar na figura 1.

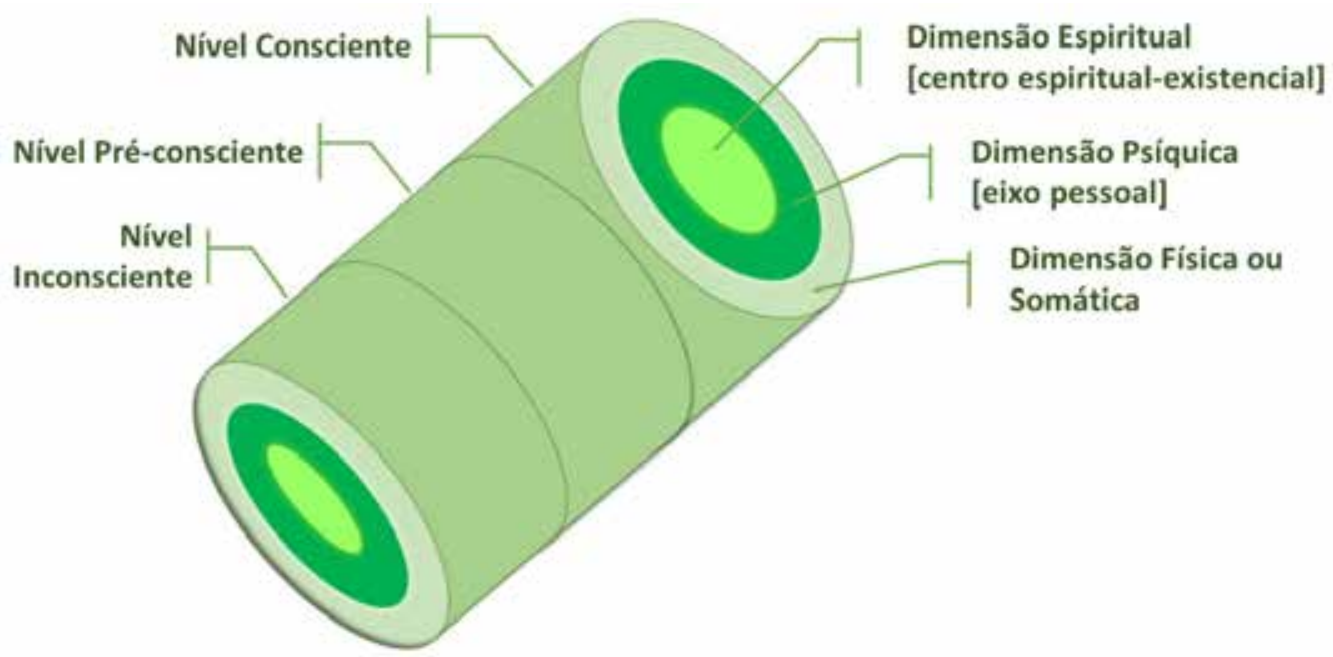

Figura 1. Estratificação das dimensões do humano. Elaborada com base na imagem retirada da obra $\mathrm{A}$ presença ignorada de Deus, de Frankl (1988/2007, p. 24).

Visualizando a figura 1 é notório que Frankl (1988/2007) buscou dar um lugar singular à dimensão espiritual, provocando a investigação das profundezas do inconsciente espiritual, o que significa dizer que o inconsciente não é composto apenas de conteúdos instintivos, além disso é combinado com elementos espirituais. Ou seja, o humano não é só impulsionado, mas ele é responsável e livre para tomar suas decisões e é quando ele se apropria dessa condição que ele se torna genuinamente ele próprio.

Por isso, na concepção de homem frankliana, influenciada pelo filósofo Max Scheler, a espiritualidade é compreendida como uma dimensão constitutiva, tal como as dimensões somática e psíquica que por serem "ontologicamente diferentes formam uma unidade profunda que supera os dualismos" (Herrera, 2006, p. 389). Pois, para Scheler (2003):

O espírito caracteriza-se aí fundamentalmente pelo ato de transcendência em relação à vida [...] O homem é o ente espiritual por excelência justamente porque pode tomar a totalidade dos entes como objeto de conhecimento, porque pode idear o ente como um todo. Ele é marcado, sim, por uma dimensão vital que compartilha com os animais. No entanto, é apenas com o ato de ideação [transcendência para a espiritualidade] que ele se descobre radicalmente como o ente que é ... Homem e espírito copertencem, assim, desde o princípio ... [a] posição peculiar do homem no cosmos. A essência espiritual do homem faz com que ele habite o âmbito sagrado da transcendência e se veja incessantemente ligado ao divino (pp. X-XI).
Isto é, nessa concepção, o homem se descobre quando transcende à espiritualidade, não podendo dizer "não" a esta, já que o sentido da existência do homem é realizar valores. Portanto, sentido e valor estabelecem íntima relação, já que o primeiro é próprio da existência humana e o segundo caracteriza-se por ser atemporal, essencial e mutável.

Baseada nisso, a Logoterapia trata a espiritualidade não como uma dimensão sobrenatural ou necessariamente religiosa, mas como dimensão antropológica e ontológica, o que vai para além da regulação das instituições religiosas e da normatividade disciplinar no âmbito acadêmico das ciências da religião. Por isso, para Lima (2012), Frankl não só reconhece essa dimensão na condição humana como parte desta ao conceber a Logoterapia.

Nesta direção, Frankl, com o intuito de afastar o caráter religioso do conceito de espiritualidade, optou por nomeá-la como "dimensão noética" - vem do grego e significa razão, espírito -, aproximando-a dos fenômenos humanos. Considerando que, o homem é um ser que pode se orientar pelos valores e encontrar, perceber, conhecer, experimentar e realizar sentido (Houaiss, 2009; Lima, 2012). Desse modo, os três fundamentos da Análise Existencial (fundamentação filosófica) e da Logoterapia (método psicoterápico), são: a liberdade da vontade que compreende a liberdade interna/espiritual frente aos aspectos biopsicossociais; a vontade que busca o sentido e o valor, isto é, o homem é "basicamente motivado pela vontade de sentido que busca descobrir o sentido presente nas realidades humanas e tornar real os valores nas situações históricas concretas” (Herrera, 2006, p. 390, tradução nossa); e o sentido da vida, o qual "não pode ser dado. Tem que ser encontrado pela própria pessoa 
- mas não dentro dela ... sentido é objetivo. É por isso que só se pode encontrar o sentido ... não podemos atribuí-lo ao nosso bel-prazer" (Frankl, 2003, p. 27, grifos do autor).

Assim, não podemos dar sentido às coisas, mas sim extrair, buscando-o até encontrar, a partir das nossas experiências, podendo "ser descoberto ao realizar valores em três dimensões" (Herrera, 2006, p. 390, tradução nossa): valores de criação (o homem dá ao mundo em forma de trabalho), valores de experiência (o que o homem recebe do mundo em forma de vivência estética) e valores de atitude (postura assumida pelo homem diante da tríade trágica: sofrimento, culpa e morte). Portanto, "para se descobrir o sentido da própria existência ... há três experiências principais: o amor a alguém, o serviço a um ideal, e a aceitação do sofrimento inevitável em nome de algo maior" (Frankl, 2003, p. 67).

Assim sendo, Herrera (2006) afirma que, para a antropologia existencial - fundamentação filosófica para o método psicoterápico da Logoterapia -, o ser humano é:

(...) único, irrepetível, insubstituível, chamado à liberdade; chamado a responder de si mesmo perante aos demais e perante a si mesmo por meio de sua consciência; chamado a descobrir o significado ou sentido e chamado a realizar os valores nas situações concretas de sua história; movido basicamente pela vontade que busca o sentido ... por sua capacidade de autotranscendência ... que o relaciona com os demais seres humanos; chamado a encarar sua radical finitude expressada na tríade trágica ... de sofrimento, dor, culpa e morte, chamado à abertura da dimensão suprahumana, da suprapessoa ou Deus (Herrera, 2006, p. 389, tradução nossa).

Ontologicamente, do ponto de vista frankliano, a origem da consciência tem um vínculo transcendente, isto é, há uma instância extra-humana na consciência "a partir da qual se revela a transcendência essencial do inconsciente espiritual" (Frankl, 1988/2007, p. 51). Visto que, a consciência tem caráter pessoal e, por isso, remonta à "reprodução ou imagem fiel da pessoa” (p. 50). Assim, a consciência se constitui como um fenômeno transcendente e

(...) só será inteligível a partir de uma região extra-humana ... Em outras palavras, para explicar a condição humana de ser livre é suficiente basear-nos na sua existencialidade; porém, para explicar a condição humana de ser responsável, precisamos recorrer à transcendentalidade de ter consciência (Frankl, 1988/2007, p. 50).

Portanto, a consciência vem de e vai para a transcendência. Então, somente através dela é possível apreender, por meio da experiência sensorial, o aspecto espiritual inerente à condição humana. No entanto, nem todos os seres humanos conseguem esse feito, a estes Frankl (1988/2007) chamou de ser humano irreligioso, o qual é considerado aquele que não ultrapassou a facticidade psicológica, questionando à sua consciência sua origem, tampouco reconhece o caráter transcendente da consciência, portanto "deteve-se antes do tempo no seu caminho em busca de sentido" (p. 52).

Do contrário, aquele que assume o risco de seguir em busca de sentido, Frankl (1988/2007) nomeou de homem religioso, o qual, para Aquino et al (2013), é identificado por: se apoiar na fé; acreditar incondicionalmente que há um suprassentido, isto é, um sentido de viver, mesmo que não o compreenda racionalmente; e atribuir sentido ao sofrimento, suportando-o, pois "a pessoa interiormente pode ser mais forte do que seu destino exterior ... sempre e em toda parte, a pessoa está colocada diante da decisão de transformar sua situação de mero sofrimento numa realização interior de valores" (Frankl, 1977/2008, p. 91).

Frankl (1988/2007) realça que este homem religioso é aquele que reconhece a tendência inconsciente em direção a Deus e respeita a liberdade de decidir, o que implica que pode dizer sim (aceitar) ou não (renegar) a Deus, isto é, Deus pode se tornar consciente ou permanecer inconsciente caso sua presença seja ignorada. Nessa direção, quando o ser humano não vive para buscar o sentido e se realizar por meio dos valores, ele tende a adoecer; sendo, portanto, a transcendência "a chave para a cura" (Frankl, 1977/2008, p. 151).

Com base nesses fundamentos, Frankl (2007) propõe aplicações metodológicas à logoterapia e afirma que, no campo da psiquiatria existencial, ela é a única escola que tem desenvolvido técnicas exitosas. No entanto, é importante ressaltar que os logoterapeutas supervalorizam o encontro existencial entre as pessoas e as relações que se estabelecem entre terapeuta e cliente, não as técnicas - porém não as nega -, pois consideram que "uma abordagem puramente tecnológica em psicoterapia, pode bloquear seus efeitos terapêuticos ... [já que] a sabedoria é insuficiente sem o toque humano" (pp. 12-13, tradução nossa). Portanto, no campo psicoterápico é importante atentar para não coisificar as pessoas.

A logoterapia tem apresentado destaque no campo do tratamento das neuroses, por isso Frankl (2007) apresenta três aspectos de intervenção em tratamentos de neuroses: psicogênicas, somatogênicas e noogênicas.

As neuroses psicogênicas se referem àquele sentido convencional da palavra no campo psiquiátrico acometendo a dimensão psicológica do humano. Já as neuroses somatogênicas são as patologias que agridem a dimensão física do humano. Por fim, as neuroses noogênicas têm relação com a dimensão espiritual do humano, pois surgem de problemas existenciais e, 
portanto, dizem respeito à compreensão logoterapêutica da patologia do nosso tempo: vazio existencial e sentimento de falta sentido, o que tem sido um desafio à psiquiatria, já que esta, por mais que mostre que até o fim da vida há sentido, não pode apontar qual é o sentido de vida do cliente (Frankl, 2003, 2007). Por isso, Frankl nos diz que:

O sentido da vida não pode ser objeto de receita médica. Não faz parte da missão do médico dar sentido à vida do paciente; mas pode muito bem ser missão dele, por meio de uma análise existencial, pôr os pacientes em condições de encontrarem um sentido na sua vida: e o que eu sustento é precisamente que o sentido é para o paciente o encontrar em cada caso e não para o atribuirmos mais ou menos arbitrariamente (Frankl, 2010, pp. 322-323).

De tal modo, Herrera (2006) afirma que, para conduzir um tratamento, o logoterapeuta precisa ter como procedimento básico a identificação de um diagnóstico diferencial, distinguindo se o caso clínico trata-se de um quadro que acomete exclusivamente as dimensões somática e psicológica, se estas dimensões se manifestam e começam a afetar a dimensão noética (ou espiritual), ou ainda se o problema noogênico manifesta-se através das dimensões físicas e psíquicas. Para tanto, faz-se necessário solicitar e verificar análises clínicas (por exemplo: exames de sangue e urina) e testes psicológicos.

Desta feita, ao sentimento de falta de sentido - não é considerado patológico -, Frankl (2010) nomeou de vácuo existencial (também é conhecido como vazio existencial), o qual se manifesta em estados de angústia e tédio que se dão quando o homem não sabe se conforma e anseia atuar no mundo como os outros fazem (massificação da sociedade) ou se cede e faz o que os demais almejam que ele faça (totalitarismo). Além disso, Frankl (1977/2008) afirma que se dá também quando o homem não sabe o que fazer com seu tempo livre, não se apropria da livre condição de ser si mesmo e não age com responsabilidade diante das próprias decisões.

Aos casos de vácuo existencial, Frankl (2010) referiu-se como a caracterização da neurose coletiva na atualidade, especificamente no século XX, porém podemos estender ao início deste século XXI, pois estamos vivenciando um momento sócio-histórico que temos lidado com o tempo em um estilo frenético, sem pausas para passar saudavelmente pelo vazio existencial. Portanto, na contemporaneidade, essa neurose de massa que tem sido o vazio existencial "pode ser descrito como forma privada e pessoal de niilismo [...] [que] pode ser definido como a posição que diz não ter sentido o ser (Frankl, 1977/2008, p. 151), incitada pelo sentimento da falta de sentido.

Frankl (2003) ao discorrer sobre a sede de sentido experimentada pela sociedade atual - em países ocidentais, comunistas e subdesenvolvidos -, constata um processo de “"“adoecimento" espiritual” (p. 10) progressivo da humanidade, expresso através das neuroses coletivas: suicídio (depressão), criminalidade (agressão) e dependência de drogas (adicção); ainda somada às crises dos aposentados e dos idosos (Frankl, 2003, 2010). Vinculada a isso, estão associadas às neuroses coletivas à tríade trágica - sofrimento, culpa e morte.

É importante ter ciência que Frankl (1977/2008) não desconsidera a finitude e a condição restrita de liberdade na vida cotidiana do humano, mas afirma que ele precisa livremente posicionar-se frente aos fatores condicionantes, tais como a hereditariedade, os aspectos biopsicossociais e o meio ambiente. Além disso, considera que

Mais humano ainda é questionar se a vida tem algum sentido. Tal atitude é, além disso, um sintoma de amadurecimento espiritual: significa que a pessoa não se limita genericamente ao que lhe dizem os ideais e valores tradicionais, mas tem a coragem de lutar por um sentido pessoal, de procurá-lo por conta própria, com autonomia (Frankl, 2003, p. 13, grifo do autor).

Nesse contexto, fica explícito que Frankl (1977/2008) valoriza o contexto sócio-histórico para construir seu pensamento, tanto no que se refere às neuroses coletivas de cada época como às psicoterapias mais indicadas para cada uma delas.

Frankl (2010) também compreende que, a partir de pesquisas empíricas que resultaram em dados estatísticos realizadas nos Estados Unidos, cerca de $20 \%$ das neuroses são geradas por esta frustração existencial, isto é, o paciente põe em dúvida o sentido da sua vida ou já entrou em desespero por não encontrar um sentido para a vida. Portanto, o campo médico tem vivenciado a modificação do perfil dos clientes que lhe chega não mais com um problema de ordem médica, mas com uma demanda de natureza filosófica, já que "a consulta médica transformou-se num posto de escuta para todos os desesperados da vida, para todos os que duvidam do sentido da sua vida” (p. 28). A este tipo de sofrimento, Frankl (1977/2008, 2010) nomeou de neuroses noogênicas e entende que se tratam da frustração existencial condensada em sintomas neuróticos, tendo como problemática central a frustração da vontade de sentido. À vista disso, "o espírito precisa do sentido - do nous, do logos -, assim como a enfermidade noogênica precisa de um tratamento logo-terápico" (Frankl, 2010, p. 107, grifos do autor).

É válido saber que, sobre as aplicações da logoterapia, Frankl (2007) alerta que esta não deve aplicar todas as técnicas em casos de psicose e suicídio; e salienta contraindicações específicas a estes casos e a indica para casos de neuroses somatogênicas, psicogênicas e, especialmente, noogênicas. Já que, antes de recorrer à 
intervenção medicamentosa de psicofármacos, buscará intervir "utilizando-se de uma psicoterapia orientada pelo espírito, dar ao doente um apoio espiritual proporcionando-lhe uma ancoragem no mundo do espírito" (Frankl, 2010, pp. 30-31, grifos do autor).

Logo, as funções do logoterapeuta frente a estas questões são: compreender a pessoa em sua totalidade, valorizando a relação e o encontro humano, assumindo uma postura de "abertura, proximidade, genuinidade e respeito" (Herrera, 2006, p. 394); facilitar a crescente autonomia no processo de autoexploração e análise da pessoa, para que ela possa ser responsável pela sua existência através de suas livres escolhas e da própria construção de seu projeto existencial; e, utilizar técnicas adequadas ao caso e, quando conveniente, compartilhar experiências pessoais com o intuito de "favorecer a livre e fluida expressão dos sentimentos, emoções, experiências, condutas e conclusões" (p. 394) da pessoa acolhida.

Frankl (1977/2008) adiciona a esta lista que o logoterapeuta tem como função favorecer que o paciente tome consciência do que "ele realmente anseia na profundidade do seu ser" (p. 128). Tendo em vista essas questões, Frankl (2010) afirma que a logoterapia, assim como a análise existencial, se trata de um campo que estabelece fronteira entre a medicina e a filosofia, entre a medicina e a religião. Assim, com o objetivo de sistematização, Frankl (2007) propôs duas técnicas logoterápicas, a saber: intenção paradoxal e derreflexão.

A técnica da intenção paradoxal consiste na provocação ao paciente de se distanciar de si e de sua neurose, substituindo seu temor por um desejo paradoxal, isto é, absurdo e antagônico ao seu, pois Frankl (1977/2008) concebe que o temor "produz exatamente aquilo que o paciente teme" (p. 145).

Então, os logoterapeutas convidam que o paciente intencione com precisão aquilo que teme, ainda que por um instante, com o intuito que ele inverta sua atitude e consiga se dar conta de sua capacidade de autodistanciamento e de autodireção em busca da cura. Assim, esta técnica trata-se de um instrumento utilizado nos tratamentos de casos provenientes de uma frustração existencial, independentemente de sua base etiológica, caracterizados por angústia, fobias e condutas obsessivo-compulsivas com frequente incidência de neurose sexual, sobretudo com o quadro de ansiedade antecipatória subjacente. Também é indicado em casos de distúrbios do sono (Frankl, 1977/2008; Frankl, 2007; Herrera, 2006).

A outra técnica, derreflexão, é utilizada quando o paciente apresenta uma situação patogênica - gera sofrimento e pode levar a uma patologia de fato - em que há hiperintenção, hiper-reflexão ou hiperatenção, pois "a intenção excessiva impossibilita o que desejamos" (Frankl, 1977/2008, p. 147). Ou seja, quanto maior o desejo, mais improvável que a ação se reali- ze. Assim, o logoterapeuta orienta o "paciente para a sua vocação e missão específica na vida” (p. 151), auxiliando-o a refocalizar a atenção e a intenção no objeto apropriado. Esta técnica é indicada nos casos derivados da frustração existencial provocada pelos sentimentos de falta de sentido e de vazio existencial. Como exemplos temos as neuroses de angústia e sexuais, como problemas de ejaculação precoce, dentre outros (Frankl, 2007; Herrera, 2006).

Frankl (1977/2008) afirma que ambas as técnicas são dispositivos terapêuticos utilizados a curto prazo, mas seus efeitos não são apenas temporários, o que pode comprovar com sua experiência clínica. Portanto, é um equívoco estabelecer uma relação direta entre duração e efeitos de uma psicoterapia. Visto que, o foco da logoterapia é buscar responder às necessidades singulares de cada pessoa, por isso, se mostra um sistema terapêutico aberto por fazer uso de suas técnicas específicas e de demais sistemas compatíveis, tais como a Gestalt (pela valorização do tempo presente), alguns aspectos de terapias corporais e a interpretação dos sonhos da psicanálise empregada no contexto analítico-existencial (Herrera, 2006).

No entanto, nada disso é possível, enquanto intervenção, quando o logoterapeuta se defronta com um caso clínico no qual o sofrimento não cessa, como em um caso de uma patologia irreversível que o paciente aguarda a morte. Ainda assim, a função dele não é prestar consolo, mas provocar reflexão sobre a utilidade da vida do cliente, isto é, o sentido da vida vivida e do sofrimento vivenciado (Frankl, 2010). Aliás, Frankl nos alerta que:

Não é necessário sofrer para encontrar o sentido. Além disso, é somente o sofrimento imposto pelo nosso destino que traz em si possibilidades de sentido; quem sofre desnecessariamente não é heroico, mas masoquista. ... O ser humano não consegue nem mesmo manter-se em perfeitas condições psico-higiênicas se nunca estiver sujeito a alguma tensão. O que não significa, porém, que deva sempre andar sofrendo (Frankl, 2003, p. 50).

Isto porque, "nem todo conflito é necessariamente neurótico; certa dose de conflito é normal e sadia. De forma similar, o sofrimento não é sempre um fenômeno patológico ... pode ser uma realização humana" (Frankl, 1977/2008, p. 127).

Destarte, Herrera (2006) aponta que as metas do processo logoterapêutico são:

a) identificar se o sofrimento do paciente é de ordem somática, psicológica ou afeta a dimensão existencial-espiritual;

b) "procurar descobrir não só o quão doente o paciente está, mas o ser humano na doença” (p. 393, 
tradução nossa); facilitar que o paciente descubra suas habilidades por meio da auto-exploração e tome consciência da liberdade que tem diante das possibilidades de escolhas, responsabilizando-se por cuidar de sua própria existência, considerando suas condições e o contexto sócio-histórico no qual está inserido;

c) concientizar-se que se responsabilizar em descobrir o sentido de sua vida no "trabalho, comunidade, amor, sofrimento, culpa, morte e transcendência” (393, tradução nossa) implica em uma urgente obrigação existencial;

d) descobrir "um vasto horizonte (por que viver, para que, para quem viver: o ser e o sentido de vida como elementos básicos) no qual pode realizar valores de criação, de experiência ou de atitude, em resposta a questões concretas da vida" (394, tradução nossa); e,

e) descobrir que localizar-se no tempo presente the possibilita a integração com o valor do passado e com as potencialidades do futuro, as quais podem suscitar experiências repletas de sentido e valor.

Frankl (1977/2008) acrescenta que, por se tratar se um processo analítico, a logoterapia tem como tarefa facilitar ao paciente que este encontre sentido em sua vida, conscientizando-se do espírito oculto de sua existência, isto é, da sua dimensão espiritual.

Diante do exposto, é inegável a marcante influência de Viktor Emil Frankl na história da psiquiatria e da psicoterapia no século XX, estendendo- se aos dias atuais, e destacando-se, especialmente, por ir além das dimensões somáticas e psicológicas do indivíduo, possibilitando a ampliação da compreensão da dimensão espiritual no homem que está aberto à possibilidade da transcendência. Em sequência, outro médico será apresentado pelo destaque no campo psicoterápico por levar em consideração a espiritualidade humana.

\subsection{Espiritualidade na Psicologia Analítica de Carl Gustav Jung}

Carl Gustav Jung (1875-1961, 86 anos) nasceu em Kesswil, Suíça. Médico psiquiatra. Tese de doutoramento, defendida em 1902, intitulada por Sobre a psicologia e a patologia dos fenômenos chamados ocultos. Pai e familiares próximos eram pastores luteranos. Criou a Psicologia Analítica, termo cunhado em 1913 para distinguir da Psicanálise freudiana.

Jung recebeu críticas por algumas aproximações entre a psicologia e outros saberes, por isso afirmou em uma carta endereçada a um teólogo protestante: "não sou espírita, ao escrever acerca dos fenômenos extrassensoriais, nem artista, ao tratar de história da arte, nem fundador de uma nova religião ou reformador do dogma, ao fazer psicologia comparada e história do pensamento" (Jung, 1971/2012d, p. 123). Vale salientar que Frankl teve idênticas preocupações com relação a pensar espiritualidade e religiosidade com um marco psicológico.

Jung teve expressiva colaboração às teorias e técnicas psicoterápicas quando propôs que não existia apenas o inconsciente freudiano - aquele composto pelas vivências pessoais reprimidas -, mas que a psique é estruturada pelas camadas: consciente, inconsciente pessoal ou individual e inconsciente coletivo ou impessoal. Igualmente, Frankl propôs uma nova estrutura para o inconsciente freudiano, propondo um inconsciente espiritual presente inclusive naqueles chamados ateus. A presença de símbolos religiosos nos sonhos de todos os homens confirmaria tal proposta, pois o autor acredita que aí se daria o encontro mais autêntico com Deus, fonte de ambiguidade para os não crentes. Portanto, assim como para Jung, o inconsciente não seria apenas fonte de conflito e sofrimento e sim possibilidade de criatividade e iluminação. Então, a fim de explicar a complexidade dessa visão de homem e de mundo que fundamenta a Psicologia Analítica, ilustramos, a partir da figura 2, a composição das camadas da psique como Jung (1981/2012c) propôs.

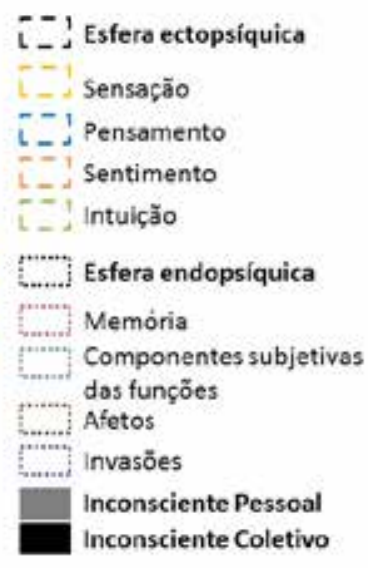

Figura 2. Sistema psíquico. Adaptação da figura "A psique" retirada da obra A vida simbólica, v. $18 / 1$, de Jung (1981/2012c, p. 59). 
Jung (1981/2012c) compreende que o sistema psíquico é composto pelas esferas ectopsíquica e endopsíquica. A esfera mais externa, ectopsíquica, está relacionada ao modo com o indivíduo se relaciona e se adapta ao mundo, à realidade externa. Portanto, Jung (1971/2012i) inquieto pelas observações acerca das semelhanças e diferenças individuais propôs um sistema de classificação nomeado: "tipos psicológicos" que refere a características e traços da personalidade. Por isso, a tipologia junguiana é bastante reconhecida no estudo das teorias da personalidade na psicologia e nos campos educacional e organizacional.

O intuito de Jung (1971/2012i) não foi padronizar ou categorizar os indivíduos, mas sim propor um modo de investigação empírica e de organização dos conteúdos relativos à psique, para que os psicólogos e pesquisadores pudessem utilizar tal instrumento para compreender a diversidade humana, de um modo diferente das tipologias antigas e modernas propostas por outros estudiosos, tais como Sócrates, Empédocles, Hipócrates, Platão, Galeno, Lombroso, Kretschemer, Sheldon, Viola e Freud. Em comum com eles, Jung tinha apenas o entendimento de que não existem tipos de natureza humana puros.

Em conformidade com a compreensão dos tipos serem entendidos como um instrumento de investigação, Zacharias (1994/2003) fez uso dessa fundamentação teórica e propôs o teste psicológico "Questionário de Avaliação Tipológica” (QUATI), reconhecido pelo Conselho Federal de Psicologia, o qual pode ser utilizado nos contextos de atuação da psicologia nas áreas clínica, organizacional e educacional.

Nessa direção, Zacharias (1994/2003) seguiu a sugestão de Jung (1971/2012i) que propunha que esta classificação fosse compreendida a partir dos entendimentos das atitudes (introversão e extroversão) e das funções de percepção ou irracionais (intuição e sensação) e das funções de julgamento ou racionais (pensamento e sentimento).

Com relação às atitudes, Jung (1971/2012i; 1971/2012b) entende que dizem respeito ao movimento e à força da energia psíquica (energia de vida), de modo dinâmico, direcionada em relação ao objeto - interno e externo -, ao magnetismo entre as pessoas, a atração por coisas, qualidades, condições e ação. Estas podem estas dispostas introvertida e extrovertidamente de modo consciente e, por existir um mecanismo compensatório no sistema psíquico, quando uma atitude for consciente, a outra estará inconsciente.

Por extroversão (E), Zacharias (1994/2003; 2006) apreende que é quando a direção da energia psíquica está voltada para o mundo externo. Portanto, pessoas extrovertidas sofrem mais influência do ambiente e tendem a ter impulso reacional diante dos estímulos que as levem para a ação; apresentam tendência a viver para depois pensar; são sociáveis, acessíveis e preferem lidar mais com coisas e pessoas que ideias; correm perigo de serem absorvidas pelos estímulos externos e se perderem neles, desconsiderando suas necessidades interiores; é a atitude mais valorizada pela cultura ocidental na contemporaneidade. Já por introversão (I), Jung (1971/2012i) e Zacharias (1994/2003; 2006) entendem que o foco da atenção está voltado para o mundo interno, ou seja, as pessoas introvertidas se dirigem para seus próprios pensamentos e sentimentos, têm interesse por acontecimentos subjetivos e tendem a resistir serem influenciadas pelo ambiente; consideram o mundo das ideias como real e são tendenciosos a desconsiderar relações e situações; dedicam-se a poucos assuntos, mas em profundidade; buscam pensar primeiro, avaliando, antes de decidir e agir.

A respeito das funções, a figura 3 ilustra bem o entendimento polar de Jung (1981/2012c), quando ele elabora a cruz das funções e as dispõem neste diagrama, pondo no centro o eu (E), o qual representa o centro da consciência (ego), guiado pela intenção da vontade que é dotada de uma quantidade de energia que controla, até certo ponto, as funções que ficam em um nível mais consciente e as que ficam mais inconscientes.

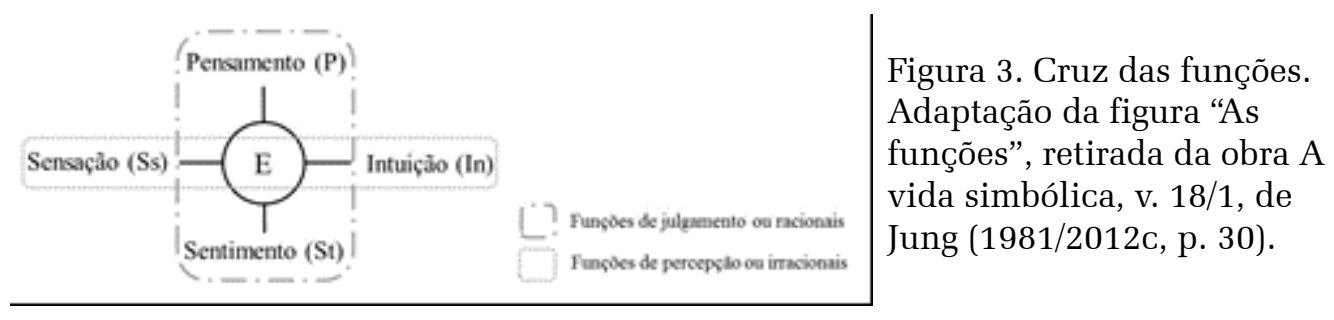

As duas funções de julgamento, também consideradas racionais, são modos de avaliação que levam à tomada de decisão. $\mathrm{O}$ pensamento $(\mathrm{P})$ avalia de forma impessoal e, baseando-se nas estruturas gerais de pensamento lógico, racional e causal, julga fatos a partir de padrões universais e coesos; seu modo de ser está voltado para dizer o que "a coisa é”, nomeando-a; tende a desconsiderar seus valores e dos outros com quem convive; esta função é asso- ciada ao elemento ar na natureza pela sua fluidez. Já o sentimento (St) realiza suas avaliações e toma suas decisões, fundamentando-se em seus próprios valores (sentimentos) e não em leis gerais; seu modo de ser está direcionado à identificação se "a coisa agrada ou não"; tem facilidade em lidar com pessoas, importando-se com elas; esta função é associada ao elemento água na natureza pela sua liquidez (Jung, 1971/2012i; Zacharias, 2006). 
Com relação às funções de percepção, tidas como irracionais, dizem respeito às formas de receber as informações do mundo externo. As pessoas da função sensação (Ss) são atentas mais aos detalhes do meio externo que ao todo, buscando a estimulação dos sentidos e, portanto, são bastante sensoriais na forma de perceber a realidade concreta, são pragmáticas e realizadoras; seu modo de ser diz que "alguma coisa existe", pois chegou por meio dos sentidos; esta função é associada ao elemento terra na natureza pela sua solidez e concretude (Jung, 1971/2012i; Zacharias, 1994/2003; Zacharias, 2006).

No entanto, as pessoas da função intuição (In) são mais teóricas que práticas, valorizam o todo em detrimento das partes, são idealistas, planejadoras, criativas e imaginativas; devido à facilidade para mudança, criatividade e imaginação, tendem a sacrificar a realidade; seu modo de ser está voltado ao palpite "de onde uma coisa vem e para onde vai"; esta função é associada ao elemento fogo na natureza, pois se trata de um fenômeno repentino que se desprende rapidamente da substância que o provocou e que não se sabe de onde vem e para onde vai concretamente (Jung, 1971/2012i; Zacharias, 2006).

Desse modo, Jung (1971/2012i) classifica oito tipos psicológicos, levando em consideração o cruzamento entre as duas atitudes e as quatro funções. Já Zacharias (1994/2003) apresenta no teste QUATI dezesseis possibilidades de tipos, pois intersecciona as atitudes, as funções principais (mais conscientes) e as funções auxiliares (mais próxima do limiar entre consciente e inconsciente). Para melhor ilustrar, observe a figura 4 .
A partir deste sistema, Zacharias (2006) alerta que é preciso entender o dinamismo da energia psíquica entre os estados consciente e inconsciente e as polaridades: introversão-extroversão, intuição-sensação e pensamento-sentimento; pois, assim, é possível entender as funções principal, auxiliares e inferior. Para essa compreensão, remete até a metáfora das fases da lua que passam da luz solar (consciência) até a escuridão (inconsciente). Desse modo, temos a lua cheia como função principal, o quarto crescente como função auxiliar, o quarto minguante como função oposta à função auxiliar e lua nova como função inferior.

Por função principal ou superior, compreende que é a dominante, aquela que se desenvolve com mais intensidade, sendo mais subordinada ao controle da consciência. Já a função auxiliar é complementar à função principal, sendo parcialmente controlada pela consciência. Vale atentar que, se a função principal for irracional, a auxiliar será irracional e vice-versa; e o oposto da função auxiliar soará ainda menos consciente. Por fim, a função inferior é aquela menos desenvolvida que permanece no inconsciente, em oposição à função principal, servindo de abertura para ele, por isso funciona como um complexo autônomo que pode vir a emergir na consciência de modo inadequado, promovendo desequilíbrio nesse sistema e até psicopatologias. Desse modo, se a função principal for intuição, a função inferior será sensação e vice-versa. O que acontece caso a função principal seja pensamento, a função inferior será sentimento. Isto, porque a compreensão tipológica é voltada às polaridades (Jung, 1971/2012i; Zacharias, 1994/2003; Zacharias, 2006).

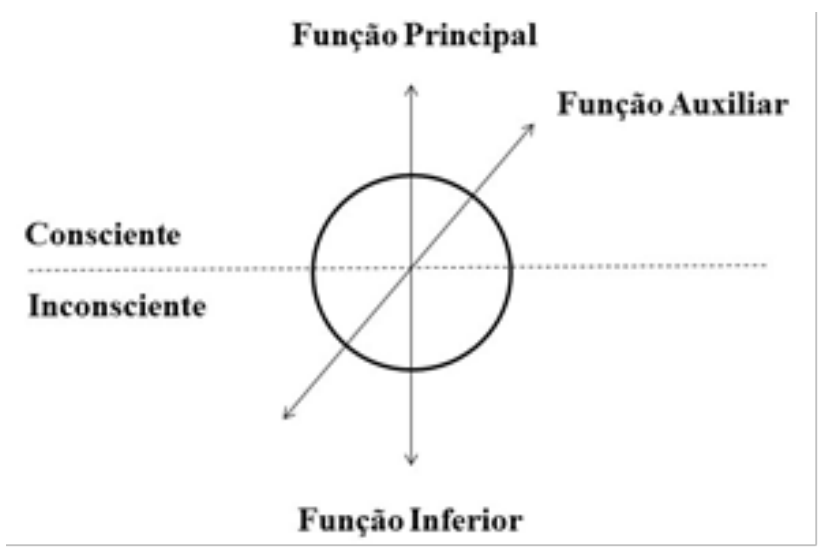

Figura 4. Sistema quaternário cruciforme. Adaptação da figura retirada da obra Tipos: a diversidade humana, de Zacharias (2006, p. 72).

Zacharias (2006) aponta que é impossível uma pessoa desenvolver todas as quatro funções no mesmo nível de consciência. Porém, é importante que o trabalho analítico na psicoterapia vislumbre o contato e a integração desses conteúdos da função inferior que são menos potencializados no que diz respeito ao seu desenvolvimento. Isto a fim de compreender sua dinâmica e se permitir aprender com ela, mas não tentar controlá-la pela vontade.

Retornando à figura 2, no que diz respeito ao campo dos fatos endopsíquicos, Jung (1981/2012c) afirma que essa esfera, ainda menos dominada pelo controle da vontade que é a ectopsíquica, tem as seguintes funções: a memória que reproduz conteúdos inconscientes; os componentes subjetivos das 
funções conscientes que dizem respeito às reações subjetivas do indivíduo impelidas por componentes sombrios, portanto inconscientes, relativos à interioridade que se personificam e se expressam no corpo; as emoções e os afetos, os quais - diferentemente da função sentimento - estão relacionados às inervações fisiológicas, tais como taquicardia e sudorese, que fogem do autocontrole; e, invasão que ocorre quando o inconsciente domina completamente e pode irromper na consciência, podendo ou não serem casos psicopatológicos, mas o fato é que o indivíduo fica "sob influência estranha" (p. 44).

Ainda na figura 2, Jung (1981/2012c) segue imergindo nas profundezas da escuridão e nos apresenta os inconscientes pessoal (ou individual) e coletivo (ou impessoal). Com relação ao inconsciente pessoal, Silveira (1997/2007) afirma que é formado por conteúdos resultantes de acontecimentos vividos que foram esquecidos, perdendo-se da memória consciente ou ainda reprimidos por se tratarem de lembranças dolorosas e desagradáveis, envolvendo grande carga afetiva. Embora tais conteúdos não tenham capacidade energética suficiente para chegarem até a camada consciente, estes podem influenciar a consciência, chegando até a suscitar sofrimentos de ordem psíquica e/ou somática.

Sendo assim, Jung (1976/2012g) diferencia os inconscientes pessoal e coletivo, afirmando que o primeiro é resultado de uma aquisição de experiências pessoais que foram reprimidas ou esquecidas e, portanto, tais conteúdos já foram conscientes e, por estarem nessa camada subjetiva, passam a serem nomeados de complexos; já ao último, atribui a condição de não ser proveniente de experiências pessoais, mas sim ser constituído de conteúdos impessoais, isto é, comuns a todos os homens, e estes são transmitidos hereditariamente, os quais são chamados de arquétipos (Silveira, 1997/2007).

Insistimos frisar que Jung (1971/2013a) entende complexos como tendo tonalidade afetiva, ou seja, são conteúdos com forte carga emocional que se expressam por imagens de uma determinada situação psíquica que é incompatível à consciência, embora tenha total coerência interior. Ademais, tem caráter autônomo e é "impossível negar sua existência” (p. 44).

Desse modo, em situações favoráveis, os complexos adquirem vida própria, vindo à tona conscientemente devido à força originária da carga emocional envolvida, portanto, podem chegar à consciência por meio de imagens representativas e sentimentos, provocando reações fisiológicas e tornando-se parcialmente resolvidos. "É como se um projétil arrebatasse a grossa camada da persona, em direção à camada obscura" (Jung, 1981/2012c, p. 64, grifo do autor), ou seja, a sombra. Em casos psicopatológicos, os complexos podem provocar invasões, ou seja, irromper o controle da vontade, gerando perturbações psíquicas neuróticas ou psicóticas, a depender do nível de dissociação da realidade consciente.
Em apertada síntese, persona diz respeito às máscaras, ou papéis sociais, necessárias à adaptação e ao convívio coletivo. Já a sombra se trata dos conteúdos que são inaceitáveis à consciência (ego), indesejados pelos indivíduos e passíveis de serem projetados em outrem. Logo, são considerados arquétipos relacionais (Nascimento, Menezes \& Lopes, 2014).

Hopcke (1989/2012) acrescenta que os complexos têm "dois componentes: o grupo de representações psíquicas e o sentimento ligado a esse grupo de representações" (p. 28). Portanto, os complexos também têm relação com o inconsciente coletivo, por eles terem temas relacionados a arquétipos. Entende-se arquétipo como conteúdos já preexistentes, moldes herdados que são representados conscientemente pelos indivíduos através de imagens similares, são também formas instintivas de conceber uma imagem ou coisa e funcionam como matrizes arcaicas, através das quais configurações análogas, tomam forma (Silveira, 1997/2007). "Seus conteúdos presumíveis aparecem sob a forma de imagens que apenas podem ser entendidas quando comparadas com paralelos histórico" (Jung, 1981/2012c, p. 61). A obra de Frankl não apresenta a mesma riqueza psicológica que a de Jung, em parte por não ser a principal preocupação do autor, tampouco suas referências teóricas se remetem a essa dimensão. Acreditamos que a opção por diferentes caminhos afaste os autores, principalmente no que diz respeito à gênese da espiritualidade, mais do que em relação à função.

Ainda sobre o inconsciente coletivo, Jung (1981/2012c) afirma que se referir a ele é sempre falar de um "como se", pois este "é a parte inconsciente da psique coletiva, a imago do objeto inconsciente” (Jung, 1976/2012g, p. 174, grifo do autor). Além disso, a psique apresenta fundamentos estruturais, isto é, um substrato comum, assim como o corpo humano anatomicamente. Tal como podemos observar nas palavras de Jung:

A ideia do inconsciente coletivo é bastante simples ... A camada mais profunda que conseguimos atingir na mente inconsciente é aquela em que o homem "perde" a sua individualidade particular, mas onde sua mente se alarga mergulhando na mente da humanidade - não a consciência, mas o inconsciente, onde somos todos iguais. Como o corpo tem sua conformação anatômica com dois olhos, um nariz e assim por diante, e apenas ligeiramente diferenças individuais, o mesmo se dá com a mente em sua formação básica. A esse nível coletivo não somos mais entidades separadas, somos um. Podemos compreender isso quando estudamos a psicologia dos povos primitivos (Jung, 1981/2012c, pp. 56-57).

Desse modo, o inconsciente coletivo se trata de uma herança comum entre todos os seres humanos, 
independente das diferenças culturais e de atitudes conscientes (Silveira, 1997/2007). Em síntese, sobre a composição dessa camada mais profunda da psique, Jung assegura que:

Compõe-se: primeiro, de percepções, pensamentos e sentimentos subliminais que não são reprimidos devido a sua incompatibilidade pessoal, mas que devido à intensidade insuficiente do seu estímulo ou pela falta do exercício da libido ficam desde o início aquém do limiar da consciência; segundo, de restos subliminais de funções arcaicas, que existem a priori e que podem ser acionados a qualquer momento através de um certo represamento da libido. Esses resíduos não são apenas de natureza formal, mas também dinâmica (impulsos); terceiro, de combinações subliminais sob forma simbólica, que ainda não estão aptas para serem conscientizadas ... O inconsciente coletivo sempre aparece projetado num objeto consciente (Jung,1976/2012g, p. 174, grifos do autor).

Assim, torna-se evidente que o inconsciente coletivo é o que conecta todos os indivíduos, tornando-os muito mais semelhantes devido às imagens primordiais que transportamos de geração em geração. Tais imagens são os conteúdos arquetípicos que compõem o inconsciente coletivo. Portanto, esse sistema psíquico é impelido pela energia psíquica (energia de vida ou libido) que circula pelas esferas ecto e endopsíquicas e pelas camadas subjetivas: consciente e inconsciente pessoal e coletivo.

Jung (1981/2012c) reflete que esse sistema se estrutura em torno do eixo ego-Self, o qual é percebido pela manifestação da força de vontade do complexo do eu (ego) que vai perdendo o controle quando se dirige à estrutura do mundo inconsciente até chegar ao centro total da personalidade (Self). Para Jung (2009), o objetivo principal do processo psicoterapêutico é a integração final da personalidade do paciente, eliminando a dissociação neurótica, podendo este caminhar sozinho, tornando-se independente em sua criatividade.

Também é perceptível que "há percepção, pensamento, sentimento, volição e intenção" (Jung, 1971/2013a, p. 133) no estado inconsciente. Estas funções psíquicas podem até parecer funcionar de modo idêntico nos estados conscientes e inconscientes, mas não é assim que ocorre. O rebaixamento do nível da consciência provoca uma crescente dissociação, aproximando-se de um nível mais primitivo, arcaico, mitológico e instintivo. Como comentamos com anterioridade, Jung e Frankl trazem importantes ampliações para o conceito de inconsciente, inclusive com o enriquecimento dessa estrutura como se pode ver nas reflexões acima. Entretanto, a ontologia frankliana contrasta com a psicologia junguiana, ao considerar, no plano espiritual as noções de liberda- de e responsabilidade, o que se confronta com a rica ideia de um inconsciente coletivo.

Nesta direção, inspirado pelos conhecimentos alquímicos sobre a união dos opostos, Jung (1971/2012e) reflete sobre a totalidade intrínseca do homem, compreendendo que ele é empírico por ser um composto de processos psíquicos e de corpo/matéria que estabelecem uma relação de reciprocidade, mas entende que também há uma dimensão transcendental, desconhecida. Isto, "para o psicólogo trata-se do si-mesmo, que de uma parte é o homem assim como ele é, mas de outra parte é a totalidade indescritível e supraempírica desse mesmo homem" (p. 362). Assim, "de algum modo deve realizar-se uma união entre opostos ... então isso somente poderá acontecer em uma terceira coisa que não represente um compromisso, mas um Novum (coisa nova) ... por meio de um ser transcendental" (p. 361, grifo do autor).

Jung (1971/2013b) entende transcendental como uma forma de existência que supera discussões sobre o paralelismo psicofísico, pois não perpassa pelos órgãos dos sentidos e nem é conteúdo psíquico, mas "situa-se em um espaço psiquicamente relativo e num tempo correspondente, isto é, em um contínuo espaço-tempo irrepresentável” (p. 97). Por isso, apoia esta definição no conceito de sincronicidade, o qual diz de coincidências significativas entre acontecimentos simultâneos e não apenas meras coincidências aleatórias e sem sentido. Destarte, os fenômenos sincronísticos são dotados de significado.

Podemos ainda associar a compreensão de transcendência com a noção de numinosidade, pois, segundo Armstrong (1994), a etimologia da palavra numinoso é derivada do latim numem, espírito, estando associada às noções de sagrado, transcendência e santidade - o divino. Logo, "a numinosidade situa-se inteiramente fora do âmbito da volição, pois transporta o sujeito para o estado de arrebatamento, numa entrega em que a vontade está inteiramente ausente" (Jung, 1971/2013a, p. 134).

Frankl considera a transcendência como igualmente fundamental, entretanto, uma vez mais, como temos chamado a atenção, o homem frankliano sempre vai encontrar-se fora de si, respondendo a um chamamento, a uma provocação que a própria vida lhe faz. Ao mergulhar dentro de nós negligenciaríamos nossa essência como existentes. Para nós, autores deste artigo, não se trata de um ajuste de contas no sentido da relevância maior de uma obra sobre a outra, e sim de salientar, neste caso, as diferenças antropológicas marcantes.

Com relação à representação simbólica dessa misteriosa união (mysterium coniunctionis) - totalidade humana -, Jung (1971/2012e) propõe que, para que possamos nos aproximar conscientemente deste entendimento, executemos o método de amplificação simbólica, o qual se trata da busca pelos núcleos que acumulam significados em torno dos símbolos. 
Outro método imprescindível é o trabalho com sonhos, pois Jung (1971/2012h) considera o conteúdo onírico como um precioso recurso da psique, por ser um processo biológico e espontâneo, no qual os símbolos são naturalmente produzidos.

Vale salientar que o símbolo é compreendido por Jung (1971/2012e, p. 366), como "as formulações melhores possíveis de fatos ainda desconhecidos, ou respectivamente inconscientes, que se comportam de maneira compensatória para com o conteúdo da consciência, ou respectivamente para com a atitude consciente", ou seja, são formados de modo natural e espontâneo pelo inconsciente, tal como os sonhos. Por isso, os símbolos funcionam como uma máquina psicológica transformadora de energia, pois eles trazem em si representações com sentido para os indivíduos que nelas depositam carga emocional, ou seja, os símbolos são passíveis de interpretações, porque são dotados de significados individuais.

Além disso, o símbolo, por causa do impulso energético que lhe é peculiar, direciona a energia para além de si mesmo e, por isso, pode ser amplificado não só no nível individual, mas também nos níveis cultural e arquetípico. Visto que, o símbolo possui em torno de si imagens arquetípicas. Desse modo, é inapreensível em sua inteireza e traz em si diversas possibilidades de compreensão simbólica, porque seu sentido vai além do significado convencional (Jung, 1971/2012b).

Portanto, refletindo sobre a vida simbólica necessária do humano e a relação com a saúde psicológica e espiritual, Jung (1981/2012c) se refere à necessidade da cooperação das imagens impessoais e atribui à religiosidade e à manutenção social de diversas religiões, a necessidade do humano de entrar em contato com seu si-mesmo (Self), o qual é projetado através de imagens arquetípicas. Dentre elas, ressaltamos o arquétipo da Imago Dei (imagem-Deus dentro da alma humana) por ser indistinguível do arquétipo si-mesmo (Hopcke, 1989/2012). No caso das religiões, as projeções são realizadas em diferentes figuras sagradas, as quais são compreendidas a partir de seus aspetos históricos. Assim, a imagem arcaica de Deus tem natureza impessoal e, portanto, tem caráter arquetípico com poderoso efeito.

Ao estudar psicologia dos povos primitivos, Jung (1981/2012c) chama atenção que a projeção dessas imagens arquetípicas são processos saudáveis e tem que ocorrer, "pois caso contrário elas invadiriam a consciência. $\mathrm{O}$ problema consiste apenas em descobrir uma forma que seja um continente adequado ... Tal meio é a iniciação religiosa” (p. 174) nos diferentes povos e culturas. Por isso, considera que "os místicos são pessoas que têm a vivência particularmente aguda do inconsciente coletivo. É a experiência dos arquétipos" (p. 115).

Desse modo, a religião é entendida como um meio de ligação misterioso entre a experiência consciente e os fatores do dinamismo inconsciente, ex- perimentada em todos as civilizações. Sendo considerada, portanto, instintiva, já que é intrínseco ao humano buscar uma relação com o transcendente (Hopcke, 2012; Silveira, 1997/2007).

Por isso, "é finalidade e aspiração dos símbolos religiosos dar sentido à vida humana” (Jung, 1981/2012c, p. 267), porém estes podem ser utilizados em prol do desenvolvimento psíquico ou ser negligenciados, mas nunca negados, devido à intensa energia que emana dos arquétipos, podendo possibilitar experiências profundas de conexão interior. Desse modo, ao reconhecer o valor dos símbolos religiosos, o indivíduo pode se vincular a alguma instituição religiosa ou vivenciar sua religiosidade de outro modo. Porém, caso não o faça, aparecerão "dificuldades, pois os fatores impessoais não encontrarão receptáculo" (p. 184). Guardadas as devidas reservas ontológicas, antropológicas e psicológicas, cremos que Frankl concordaria com a importante finalidade da espiritualidade e da religiosidade, não só para a saúde psicofísica como também para o próprio enriquecimento da personalidade como demonstra Jung de forma cabal. Nesse sentido, a obra de ambos é de uma impressionante radicalidade.

Como psicoterapeuta, ou melhor, como "psicólogo analista” (Jung, 1971/2012d, p. 121) Jung (2009) afirma que na prática da psicoterapia há uma relação pautada na interação de dois sistemas psíquicos que se influenciam mutuamente em um processo dialético. Assim, o método dialético é essencial para o processo inter-relacional entre psicoterapeuta e cliente, pois promove a ampliação das possibilidades de interpretação dos conteúdos simbólicos, favorecendo a tomada de consciência, isto é, a assimilação progressiva dos conteúdos do inconsciente. Para tanto, propõe ao tratamento analítico da alma quatro etapas, são elas:

a) O tratamento se origina pelo modelo do sacramento da confissão, pois o indivíduo revela seus segredos de modo catártico, já que vem ocultando tais conteúdos intelectuais e emocionais, consciente ou inconscientemente, considerando-os pecado e sentindo culpa. Nesta etapa, retorna à consciência do indivíduo o que foi reprimido, mas que o pertence, ou seja, é o encontro com a sombra.

b) A segunda etapa é caracterizada pelo esclarecimento, quando há a tomada de consciência da transferência e a compreensão dos conteúdos geradores do sofrimento, os quais têm condições de tornarem-se conscientes neste momento.

c) Com o intuito de alcançar uma adaptação social normal, o indivíduo passa pelo estágio da educação até que consiga ser o ser social.

d) Por fim, no estágio da transformação, o psicoterapeuta tem que se permitir ser afetado 
para que possa afetar seu paciente. Ele faz isso, reaplicando em si o sistema em que acredita, autoeducando o educador. Isto, porque ele é parte integrante do processo psíquico do tratamento, ou seja, ele também deve estar disposto às influências transformadoras.

Diante do exposto, mesmo sendo possível visualizar etapas no processo psicoterápico, Jung (1981/2012c) nos diz que "não existe uma técnica terapêutica ou doutrina, aplicáveis em geral, pois cada caso submetido a tratamento é um indivíduo numa situação específica de vida” (p. 243), por isso é necessário se permitir às nuances de cada experiência, tomando-a como nova para que seja possível "encontrar a abordagem individual ... Tudo depende de saber se sou capaz de aprender a linguagem do paciente e se posso seguir a tateante busca de seu inconsciente por um caminho para a luz” (p. 245).

Sendo assim, o psicoterapeuta deve estar disposto a deixar aberto o caminho individual para o paciente tornar-se quem de fato é, ou seja, que ele vivencie seu processo de individuação, permitindo-se sair da unilateralidade consciente que gera sofrimento a partir da mudança da atitude consciente. Mas para isso, Jung (2009) sinaliza a exigência do trabalho pessoal, já que os psicoterapeutas também têm complexos e um ou mais pontos cegos (conteúdos sombrios) que interferem em sua atuação. Assim, os conteúdos que ainda não se tornaram conscientes no psicoterapeuta, ele busca, inconscientemente, impedir que se tornem conscientes para o paciente, ou então, percebe-os, mas de modo exagerado. No entanto, considera que é por ser afetado pelo paciente que o psicoterapeuta irá curá-lo - cura entendida como transformação -, pois "ele só vai curar na medida do seu próprio ferimento" (Jung, 2009, p. 111). Neste contexto, Jung faz analogia ao mitologema grego do médico ferido, referindo-se ao mito de Quíron, conhecido como o curador e guia interno.

As reflexões acima, respeitadas as características da obra de cada autor, inclusive a linguagem própria de cada um, apresentam importantes pontos de intercessão. A individualidade a ser considerada na ação psicoterápica, a importância da autoeducação, o cuidado que o terapeuta necessariamente deve tomar com a sua própria história, inclusive seus sofrimentos, que bem trabalhados se transformam em fontes importantes de conhecimento, comunicação e humanização; além de valiosos recursos terapêuticos.

Ao refletir sobre o homem moderno do século XX e a cultura espiritual, Jung (1976/2012a) afirma perceber um retrocesso e uma tendência ao abandono da tradição, o que gera um aumento significativo de casos com dissociação psíquica. Além disso, ressalta que não observa o sofrimento apenas nos indivíduos isolados, mas nos grupos sociais.

Nesta direção, Jung (1971/2012d) recorre a dados de pesquisas realizadas por ele mesmo e por científicos contemporâneos, e se refere a um "ho- mem arreligioso", por ser comum à época que muitas pessoas tenham perdido a fé em quaisquer concepções religiosas, sem direcionar esta fé a nenhum outro referencial. No entanto, alerta:

Enquanto a vida flui harmoniosamente sem ela, a perda não é sentida. Sobrevindo, porém o sofrimento ... A pessoa procura então subterfúgios e começa a pensar sobre o sentido da vida ... O médico é mais solicitado nesses casos por judeus e protestantes e menos por católicos (Isto é assim porque a Igreja católica se sente responsável pela cura animaruin, pela cura das almas). Acredita-se na ciência e por isso são colocadas hoje aos psiquiatras as questões que antigamente pertenciam ao campo do teólogo ... Desde tempos imemoriais, as pessoas criaram concepções de um ou mais seres superiores e de uma vida no além. Só a época moderna acredita poder viver sem isso (Jung, 1981/2012c, p. 266, grifos do autor).

Com esta última frase da citação, na qual Jung (1981/2012c) lamenta a experiência do homem arreligioso moderno, fica explícito o posicionamento da psicologia analítica frente à religiosidade, no que se refere à importância e ao sentido da religiosidade, como modo de expressão da espiritualidade e da fé, independente de qual seja a religião. Por isso, o psicólogo clínico deve ser responsável para com sua ciência e não negligenciar a experiência real dos fatos, mesmo que eles não estejam ainda passíveis de conceituação científica.

Reflexão muito semelhante realiza Frankl, responsabilizando a II Guerra Mundial e suas consequências pela perda da tradição que guiava o homem, tanto no cotidiano como em seus momentos de sofrimento e perplexidade. Do mesmo modo que Jung, o autor se preocupa com o que chama de vazio existencial. Ambos questionam o poder da ciência para fazer frente a esta perda, salientando a verdadeira ilusão de nosso tempo moderno: a de ser possível viver com as respostas que nos dá a ciência, ofuscados em nossa espiritualidade e transcendência.

\section{Considerações Finais}

Dentre as teorias e técnicas psicoterápicas que levam em consideração a religiosidade e a espiritualidade na psicologia, selecionamos a Logoterapia (Frankl) e a Psicologia Analítica (Jung). As ideias dos teóricos e clínicos demonstram mais aproximações que afastamentos no que diz respeito às temáticas abordadas ao longo das reflexões supracitadas. Ambos têm influência filosófica da fenomenologia e de alguns aspectos da psicanálise freudiana. Comungam que a religiosidade, isto é, a vivência de uma prática institucionalizada de uma religião - sistema 
de crenças, dogmas e valores socialmente compartilhados -, não é obrigatória para que o homem experiencie a espiritualidade. Embora a religião seja sim um meio significativo de expressão da dimensão espiritual, constituindo-se como uma alternativa importante de favorecer o homem a atribuir sentido às suas experiências de sofrimento.

Também concordam que o homem religioso é aquele que quando toma consciência de sua condição ontológica de transcendência - na perspectiva frankliana, reconhece a existência do seu inconsciente espiritual e, portanto, a tendência em direção a Deus, responsabiliza-se pelas escolhas feitas livremente e encontra o sentido de viver em experiências concretas; do ponto de vista junguiano, em seu processo de desenvolvimento psíquico, toma consciência, através da aproximação do eixo ego-Self, da influência do arquétipo Imago Dei nos níveis coletivo e individual, e a experiência no mundo consciente, vivenciando sua religiosidade; assim, se aproxima da complexa totalidade, inteireza, integração e unidade entre as dimensões humanas e, desse modo, vive a vida de um modo mais saudável, pois encontra formas de lidar com o sofrimento do existir humano, baseando-se nos tipos psicológicos que dizem respeito à diversidade e à singularidade humana $\mathrm{e}$ seus modos de adaptação ao mundo.

Ambos valorizam a religiosidade com sentido como sendo uma forma de promoção da saúde espiritual e reconhecem que esta esfera influencia nas demais dimensões humanas. Por isso, refletem sobre os prejuízos da não vivência religiosa na formação do humano que, na contemporaneidade, tem apresentado dificuldades para lidar com os desafios cotidianos e o sofrimento inerente a existência. Além disso, partilham da ideia que a espiritualidade - tida como experiência com o numinoso, a conscientização da experiência religiosa e da dimensão espiritual - é o que diferencia o homem dos demais seres vivos, possibilitando que ele atribua sentido à vida, condição ontológica do humano.

No entanto, há uma divergência notória na compreensão da fundamentação ontológica do ser religioso. Visto que, para Jung, a espiritualidade é uma vivência que se refere à conscientização de que há uma instância maior que a consciência - ego - e que para lidar com o sofrimento da existência e buscar a saúde psíquica é preciso conectar-se com o numinoso em busca do Si-mesmo (Self - centro total da personalidade), experiência esta que se dá através da religião - não necessariamente a religiosidade, isto é, a vivência de uma prática institucionalizada - que tem caráter instintivo. Já Frankl discorda dessa perspectiva de atribuir caráter instintivo à dimensão espiritual, pois ele compreende que o humano, dotado de um inconsciente espiritual, é convidado a buscar o sentido nas coisas, nas pessoas e na vida e é atraído pelo sentido de valor, porém não é impulsionado por nenhuma instância.

\section{Referências}

Aquino, T. A. A. de, Dantas, C. T. A. C., Medeiros, I. F., Moraes, I. O. A. L. de, Melo, M. de O., Nascimento, N. M. C. do, Andrade, S. F. de O., Abrantes, M. do S., \& Pires, V. N. (2013). Estilos de fé e sentido da vida. Psicologia Argumento (Curitiba), 31(75), 665-676. Recuperado em 22 de agosto de 2016, de https://dx.doi:10.7213/psicol.argum.31.075.AO04

Armstrong, K. (1994). Uma história de Deus: quatro milênios de busca do judaísmo, cristianismo e islamismo. São Paulo: Companhia das Letras.

Cavalheiro, C. M. F., \& Falcke, D. (2014). Espiritualidade na formação acadêmica em psicologia no Rio Grande do Sul. Estudos de Psicologia (Campinas), 31(1), 35-44. Recuperado em 22 de agosto de 2016, de https://dx.doi.org/10.1590/ 0103-166X2014000100004

Chopra, D., \& Mlodinow, L. (2012). Ciência x espiritualidade: dois pensadores, duas visões de mundo. Rio de Janeiro: Sextante.

Dalgalarrondo, P. (2008). Religião, Psicopatologia e Saúde Mental. Porto Alegre/RS: Artmed.

Frankl, V. E. (2003). Sede de sentido. ( $3^{\mathrm{a}}$ ed.). São Paulo: Quadrante.

Frankl, V. E. (2007). A presença ignorada de Deus. (10ª ed.). São Leopoldo: Sinodal; Petrópolis: Vozes. (Texto original produzido em 1988).

Frankl, V. E. (2007). Fundamentos y aplicaciones de la logoterapia. Buenos Aires: San Pablo.

Frankl, V. E. (2008). Em busca de sentido: um psicólogo no campo de concentração. (25 a ed.). (W. O. Schlupp, Trad.). São Leopoldo: Sinodal; Petrópolis: Vozes. (Texto original publicado em 1977).

Frankl, V. E. (2010). Psicoterapia e sentido da vida: fundamentos da logoterapia e análise existencial. $\left(5^{\mathrm{a}}\right.$ ed.). (A. M. de Castro, Trad.) São Paulo: Quadrante.

Gil, A. C. (2002). Como elaborar projetos de pesquisa. ( $4^{\mathrm{a}}$ ed.). São Paulo: Atlas. (Texto original publicado em 1987).

Herrera, G. P. (2006). Viktor Frankl, comunicación y resistência. Buenos Aires: San Pablo.

Hopcke, R. H. (2012). Guia para a obra completa de $C$. G. Jung. ( $3^{\mathrm{a}}$ ed.). Petrópolis: Vozes. (Texto original publicado em 1989).

Houaiss, A. (2009). Dicionário da língua portuguesa (nova ortografia). Rio de Janeiro: Objetiva.

Jung, C. G. (2009). A prática da psicoterapia: contribuições ao problema da psicoterapia e à psicologia da transferência. Obra completa, v. 16/1. (9a ed.). Petrópolis, RJ: Vozes. (Texto original publicado em 1971). 
Jung, C. G. (2012a). Aion: estudo sobre o simbolismo do si-mesmo. Obra completa, v. 9/2. (9a ed.). Petrópolis, RJ: Vozes. (Texto original publicado em 1976).

Jung, C. G. (2012b). A energia psíquica. Obra completa, v. 8/1. (13 ${ }^{\mathrm{a}}$ ed.). Petrópolis, RJ: Vozes. (Texto original publicado em 1971).

Jung, C. G. (2012c). A vida simbólica: escritos diversos.

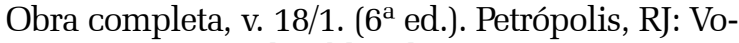
zes. (Texto original publicado em 1981).

Jung, C. G. (2012d). Escritos diversos: psicologia e religião ocidental e oriental (dos volumes 10 e 11). Obra completa, v. 11/6. ( $3^{\mathrm{a}}$ ed.). Petrópolis, RJ: Vozes. (Texto original publicado em 1971).

Jung, C. G. (2012e). Mysterium coniunctionis: pesquisas sobre a separação e a composição dos opostos psíquicos na alquimia: Rex e Regina; Adão e Eva; A conjunção. Obra completa, v. 14/2. ( $3^{\mathrm{a}}$ ed.). Petrópolis, RJ: Vozes. (Texto original publicado em 1971).

Jung, C. G. (2012f). O eu e o inconsciente. Obra completa, v. 7/2. (24 a ed.). Petrópolis, RJ: Vozes. (Texto original publicado em 1971).

Jung, C. G. (2012g). Os arquétipos e o inconsciente coletivo. Obra completa, v. 9/1. (8 ${ }^{\mathrm{a}}$ ed.). Petrópolis, RJ: Vozes. (Texto original publicado em 1976).

Jung, C. G. (2012h). Psicologia e religião: psicologia e religião ocidental e oriental. Obra completa, v. 11/1. (10 ed.). Petrópolis, RJ: Vozes. (Texto original publicado em 1971).

Jung, C. G. (2012i). Tipos psicológicos. Obra completa, v. 6. ( $6^{\mathrm{a}}$ ed.). Petrópolis, RJ: Vozes. (Texto original publicado em 1971).

Jung, C. G. (2013a). A natureza da psique. Obra completa, v. 8/2. (10 ed.). Petrópolis, RJ: Vozes. (Texto original publicado em 1971).

Jung, C. G. (2013b). Sincronicidade: a dinâmica do inconsciente. Obra completa, v. 8/3. (19 a ed.). Petrópolis, RJ: Vozes. (Texto original publicado em 1971).

Lima, M. E. C. (2012). A plenitude humana e o cuidado integral na perspectiva de Viktor Frankl. Dissertação de mestrado. Recife: Universidade Católica de Pernambuco.

Lima, T., \& Mioto, R. (2007). Procedimentos metodológicos na construção do conhecimento científico: a pesquisa bibliográfica. Revista Katál, 10(esp.), 3745.

Nascimento, A. K. da C., Menezes, W. N. de \& Lopes, C. P. (2014). A natureza dos sonhos: o descortinar do conteúdo onírico sob um olhar junguiano. Em F. Lins, \& W. N. de Menezes (Orgs.). Múltiplos olhares em psicologia. Recife: Libertas/Estácio|FIR.

Scheler, M. (2003). A posição do homem no cosmos. Rio de Janeiro: Forense Universitária.
Silveira, N. (2007). Jung: vida e obra. (21 ${ }^{\mathrm{a}}$ ed.). Rio de Janeiro: Paz e Terra. (Texto original publicado em 1997).

Spaccaquerche, M. E. B. (Org.). (2010). Encontros em Psicologia Analítica. São Paulo: Paulus Editora.

Zacharias, J. J. de M. (2003). QUATI: Questionário de avaliação tipológica (versão II): manual. ( $5^{\mathrm{a}} \mathrm{ed}$. rev. e ampl.). São Paulo: Vetor. (Texto original publicado em 1994).

Zacharias, J. J. de M. (2006). Tipos: a diversidade humana. São Paulo: Vetor.

Ananda Kenney da Cunha Nascimento (Orcid. org/0000-0001-9070-7277), é Graduada em Psicologia (Faculdade Estácio do Recife - Estácio/ FIR, Mestra e Doutora em Psicologia Clínica pela Universidade Católica de Pernambuco - UNICAP, na linha de pesquisa Práticas Psicológicas Clínicas em Instituições. Professora colaboradora da Universidade Estadual de Londrina (UEL). Email: anandakcn@gmail.com

Marcus Túlio Caldas (Orcid. org/0000-0002-44074744) é Doutor em Psicologia pela Universidade de Deusto. Atualmente é médico psiquiatra do Governo do Estado de Pernambuco e Professor Adjunto II da Universidade Católica de Pernambuco - Universidade Católica de Pernambuco (UNICAP).

Recebido em 01.04.17

Decisão Editorial em 31.07.17 Aceito em 08.02.19 